\title{
Effectiveness of Indigenous Lead (Pb) Reducing Bacteria Consortia of Waste Water Treatment in Agar Flour Industry
}

\author{
Wasiatus Sa'diyah ${ }^{1}$, Endang Suarsini ${ }^{2}$, Ibrohim $^{2}$ \\ ${ }^{1}$ Master Program of Biology Education, Graduate Program, State University of Malang, Malang, Indonesia \\ ${ }^{2}$ Department of Biology, Faculty of Mathematics and Natural Sciences, State University of Malang, Malang, \\ Indonesia
}

\begin{abstract}
Lead $(\mathrm{Pb})$ is known as toxic element in environment. It is produced from processing of Agar Flour industry activities. Enhancement of $\mathrm{Pb}$ in the wastewater of agar flour is very dangerous for human health. Effect of lead damage some organ e.g. kidney, liver, and hair. Environment standard of lead concentration on waste water based on Governor of East Java Regulation No. 72 of 2013 is $1 \mathrm{mg} \cdot \mathrm{L}^{-1}$, otherwise, initial lead levels of waste water are $3.114 \mathrm{mg} \cdot \mathrm{L}^{-1}$. The aim of the research is reducing the level of lead to be harmless for the environment. One method to decrease a high concentration of lead in wastewater is biosorption. Consortia of Bacillus alvei and Bacillus pumilus as indigenous bacteria are used to decrease $\mathrm{Pb}$ level in the wastewater. The experiment was carried out with varies of wastewater concentration and bacteria $3 \%, 4 \%, 5 \%, 6 \%$, and $7 \%$. Consortium of B. alvei dan B. pumilus at $7 \%$ concentration have the highest potency $93.58 \%$ to reduce lead reach $0.2 \mathrm{mg} \cdot \mathrm{L}^{-1}$.
\end{abstract}

Keywords: Bacteria, Consortia, Concentration, $\mathrm{Pb}$, Waste of Agar Flour

\section{INTRODUCTION}

Industry development in Indonesia has negative impact on ecosystem. The Effects were characterized by pollution. Pollution came from pollutants [1], such as hazardous industrial waste water which badly manage. It is also found at agar flour industrial waste water in Malang city. This pollution cause many problems in environment.

Problems occured bacause heavy metal $(\mathrm{Pb})$ found in the waste of agar flour industry. These lead $(\mathrm{Pb})$ is truly toxic, non biodegradable, potentially pollute the environment $[2,3]$. It is also carcinogenic and highly toxic [4]. Therefore, to control environmental pollution by $\mathrm{Pb}$, it is necessa-ry to restrict maximum content of $\mathrm{Pb}$ in the waste water that discharged into the environment. Based on observation, $\mathrm{Pb}$ levels in the waste water of agar flour industrial are 3.114 $\mathrm{mg} . \mathrm{L}^{-1}$ which too high compared to the standard quality $1 \mathrm{mg} . \mathrm{L}^{-1}$ according Governor of East Java Regulation No. 72 of 2013.

The concentration of $\mathrm{Pb}$ higher than the standards would be harmful to living organisms, especially indirect impact on the human health, it can damage the brain which reduce the

\footnotetext{
* Correspondence author:

Wasiatus Sa'diyah

Email : wasiatusadiyah@gmail.com

Address : Master Program of Biology Education, State University of Malang, JL. Semarang No. 5 Malang, 65145
}

intelligence of children [2]. Lead cause interference on nervous system, reproductive system and urinary tract [5]. Lead enter the waters through efflorescence in the air with the help of rain water [3]. Alternative treatments should be done to avoid such health problems, especially treatment for waste problem.

Biotechnology offers a solution to the polluted environment. There are several treatments that are offered in biotechnology, in this case the solution used for this study is using bacteria for bioremediation of $\mathrm{Pb}$ contaminated environment $[6,7]$. Indigenous bacteria are used as a natural agent to reduce waste water, biosorption principle is used to minimize the impact of $\mathrm{Pb}$ [8]. Biosorption is biological process using dead cells and living cells, caused surface of cell to bind metals. Biosorption is known as the other different mechanism of bioremediation [9]. In this case, biosorption is a metal ion absorption process using indigenous bacteria as biological agents. All microbial such as bacteria has ability to absorb heavy metal from water solution. Cell walls play an important role in binding metals ions. The advantages apply biosorption method using bacteria are giving low cost due to use bacteria as biological origin of materials, it can remove heavy metals in large quantities, and metal recovery [10].

Consortia of bacteria are known to reduce the levels of $\mathrm{Pb}$ in waste water better than individual bacteria. Using the bacterial consortia was more 
effective in reducing waste [11]. Thus, this study use a consortia of bacteria to assay the rate of reducing $\mathrm{Pb}$.

\section{MATERIALS AND METHODS \\ Starter of Bacteria Isolates}

Indigenous bacteria were used for treatment. Indigenous bacteria obtained from industry of agar flour waste water, such as $B$. alvei and $B$. pumilus. Culturing bacteria used Nutrient Agar and multiply bacteria used nutrient broth. Culture starter for lead reducing experiment consist of tree starter of individual and both species of $B$. alvei and B. pumilus. Consortia starter of B. alvei and $B$. pumilus was developed using combination of both species at 24 hours age with the same volume and cell density is $3 \times 10^{8}$ cell $/ \mathrm{mL}$ of each species.

\section{Treatment}

The concentration of bacteria in the waste water used were $3 \%, 4 \%, 5 \%, 6 \%$ and $7 \%$. As a comparison this study use two control treatments, positive control and negative control. Positive control is concentration of $\mathrm{Pb}$ on sterilized waste added with sterilized aquades, while the negative control is concentration of $\mathrm{Pb}$ on unsterilized waste added with sterilized aquades. Each treatment and control take place in shaker with $100 \mathrm{rpm}$ for 7 days. After 7 days, $\mathrm{Pb}$ concentration on each treatment was measured using Atomic Absorption Spectrometry (AAS). The last result of the $\mathrm{Pb}$ concentration will compare with Governor of East Java Regulation No. 72 of 2013 [13].

\section{Statistical Data Analysis}

Statistical analysis in this study using SPSS 22.0 for Windows for analysis percentage of $\mathrm{Pb}$ reducing among treatments. If the level of significance $<0.05$, the research hypothesis is accepted and the null hypothesis is rejected. If the data showed significant results, then conducted a further test of Duncan.

\section{RESULTS AND DISCUSSION}

Biotechnology in the environment fields provides an important role to help the existing problems in the neighborhood. The aims of processing waste water is decreasing concentration of hazardous waste, thus it can fulfill as the standards quality. Method used for this problem is using bacteria as a bioremediation agent to reduce hazardous metals concentration such as $\mathrm{Pb}$ in the waste water.

Capability of indigenous bacteria to reduce the toxic effect of $\mathrm{Pb}$ could be effectively used in environmental biotechnology. Indigenous Bacteria is a mixture of a wide variety of beneficial microbe which originally lives in a particular area. It have potential in the process of biodegradation, bioleaching, composting, and nitrogen fixation [14]. In this study, we used bacteria that are a native bacterium of agar flour waste water. Bacteria that isolated and identified from waste water are Bacillus alvei and Bacillus pumilus. These bacteria tested in laboratory scale to determine its benefits for reducing $\mathrm{Pb}$ which contained in the waste water.

Test result (Fig. 1) showed that indigenous bacteria can reduce $\mathrm{Pb}$ concentration. Initial $\mathrm{Pb}$ concentration of waste water is $3.114 \mathrm{mg}^{-L^{-1}}$, after 7 days each single treatment able to reduce $\mathrm{Pb}$ levels. Increasing of culture concentration at 7 days experiment showed increased of percentage of $\mathrm{Pb}$ reducing. Starter of $B$. alvei, B. pumilus, and consortia of both species are able to reduce of $\mathrm{Pb}$ concentration until 0.910 mg.L11 (70.78\%), 1.544 mg. $\mathrm{L}^{-1}$ (50.41 \%), and $0.200 \mathrm{mg} \cdot \mathrm{L}^{-1}$ (93.58 \%) respectively at culture concentration $7 \%$. The figure 1 showed percentage of $\mathrm{Pb}$ reduction among treatments. Consortia of $B$. alvei and $B$. pumilus at $7 \%$ culture concentration in 7 days experiment have highest percentage of $\mathrm{Pb}$ reduction.

Effectiveness of bacteria consortia is due to the synergistic action of both species in the broth culture or due to different metabolism pathway by individual bacteria $[15,16]$. Bacillus alvei and Bacillus pumilus are indigenous bacteria that are exploited from waste water. Indigenous bacteria of both species from $\mathrm{Pb}$ contaminated habitat was adapted and it can still grow on their environment. Reducing $\mathrm{Pb}$ levels by bacteria consortia produced significantly higher and more efficient results [17].

Indigenous bacteria have the ability to reduce $\mathrm{Pb}$ concentration in the agar flour waste water significantly. In this case, Bacillus identified from agar flour waste water. Bacillus is Gram positive and aerobic. Gram positive bacteria have the ability to bind heavy metal compared to Gram negative bacteria, because its cells wall structure, it contains peptidoglycan, teichoic, teichuronic acid that responsible for $\mathrm{Pb}$ binding. Phosphate and carboxyl group in the cells wall also plays an important role to bind $\mathrm{Pb}[17,18,19]$. Bacillus used by many researchers to investigate the 
reduction of $\mathrm{Pb}$, because it has high potential of reduction to remove heavy metal and also as biosorbent, for reducing $\mathrm{Pb}$ based on biosorption principal $[20,21]$.

Biosorption of $\mathrm{Pb}$ by consortia of $B$. alvei and $B$. pumilus was highest at $7 \%$ culture concentration. Culture concentration indicates the number or density of bacterial cells that affect the biosorption process. The culture concentration $7 \%$ in 7 days experiment have highest potency to $\mathrm{Pb}$ reduction, $\mathrm{Pb}$ level reduce to be $0.200 \mathrm{mg} \cdot \mathrm{L}^{-1}$ (thus absorbed $\mathrm{Pb}$ reached 2.914 (mg. $\mathrm{L}^{-1}$ ) or $93.58 \%$ ). The results appropriate with the aim of biosorption to reduce concentration of environmental pollutant [22].

Degradation of wastes by bacterial consortia is highly significant [17]. Based on stastistical data analysis, value of $\mathrm{Pb}$ reduction by bacteria decrease significantly and also it fullfill quality standard of Governor of East Java Regulation No. 72 of 2013 [13], that Pb level after treatment harmless than $\mathrm{Pb}$ level before treatment.

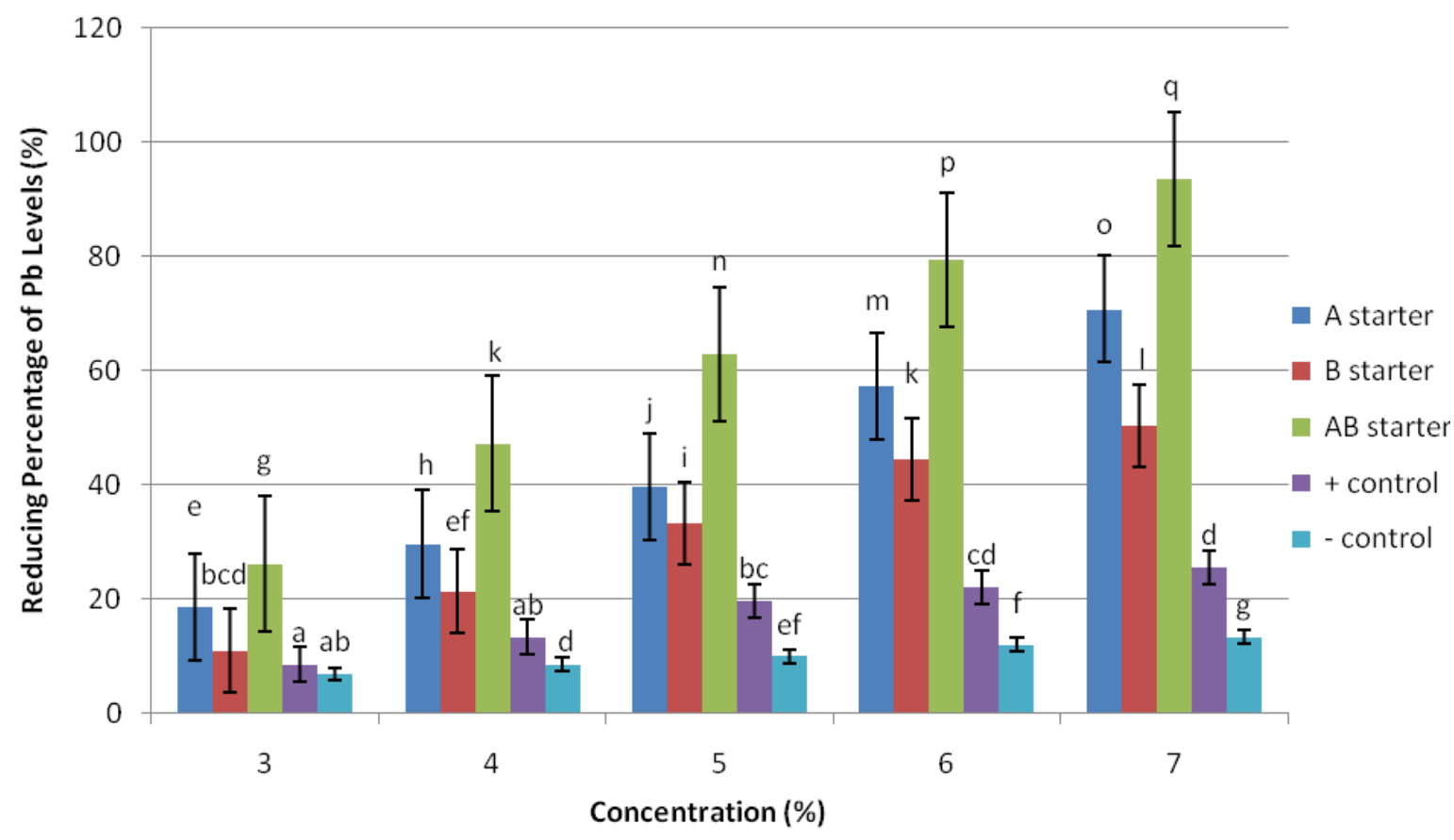

Figure 1. Reducing of $\mathrm{Pb}$ levels with each concentration and starter

\section{CONCLUSIONS}

Consortia of $B$. alvei and $B$. pumilus reduce $\mathrm{Pb}$ concentration higher than individual species. The culture concentration of the bacteria consortia at $7 \%$ have highest potency $93.58 \%$., it reduced $\mathrm{Pb}$ concentration to be $0.200 \mathrm{mg} \cdot \mathrm{L}^{-1}$; it fulfill standard quality Based on Governor of East Java Regulation No. 72 of 2013.

\section{REFERENCES}

[1] Sastrawijaya, A.T. 1999. Pencemaran lingkungan. Rineka cipta: Jakarta.

[2] Ekere, N.R., J.N. Ihedioha., T.I. Oparanozie., F.I. Ogbuehi-Chima, J. Ayogu. 2014. Assesment of some heavy metals in facial cosmetic product. J. Chem. Pharm. Res. 6(8). 561-564.

[3] Widiyanti, C.A., Sunarto, N.S. Handajani. 2005. Kandungan logam berat timbal $(\mathrm{Pb})$ serta struktur mikroanatomi ctenidia dan kelenjar pencernaan (hepar) Anadonta woodiana Lea., di Sungai Serang Hilir Waduk Kedung Ombo. BioSMART. 7(2). 136-142.

[4] Fu, F., W. Qi. 2012. Removal of heavy metal ions from waste waters: a review. J. Environ. Manage. 92. 407-418.

[5] Stancheva, M., L. Makedonski, E. Petrova. 2013. Determination of heavy metals ( $\mathrm{Pb}$, $\mathrm{Cd}$, As and $\mathrm{Hg}$ ) in Black SeaGrey Mullet (Mugil cephalus). Bulgarian J. Agr. Sci. 19 (Suppl.1). 30-34.

[6] Nies, D.H. 1999. Microbial heavy metal resistance. Appl. Microbiol. Biotechnol. 51. 730-750.

[7] Singh, R., P. Singh, R. Sharma. 2014. Microor-ganism as a tool of bioremediation techno-logy for cleaning environment. Proc. Int. Acad. Ecol. Environ. Sci. 4(1). 1-6. 
[8] Yunilas, L. Warli, Y. Marlida, I. Riyanto. 2013. Potency of indigenous bacteria from oils palm waste in degrades lignocellulose as a sources of inoculum fermented to high fibre feed. Pakistan J. Nutr. 12(9). 851-853.

[9] Dixit, R., Wasiullah, D. Malaviya, K. Pandiyan, U.B. Singh, A. Sahu, R. Shukla, B.P. Singh, J.P. Rai, P.K. Sharma, H. Lade, D. Paul. 2015. Bioremediation of heavy metals from soils dan aquatic environment: an overview of principles and criteria of fundamental processes. Sustain. 7. 2189-221.

[10] Swiatek, M.Z., M. Krzywonos. 2014. Potential of biosorption and bioacumulation process for heavy metal removal. Pol. J. Environ. Stud. 23(2). 551-561.

[11] Sastrawidana, I D.K., B.W Lay, A.M. Fauzi., Dwi Andreas Santosa. 2008. Pemanfaatan konsorsium bakteri lokal untuk bioremediasi limbah tekstil menggunakan sistem kombinasi anaerobik-aerobik. Berita Biologi. 9(2).

[12] Mahmood, R., S. Faiza, A. Sikander. 2012. Isolation of indigenous bacteria and consortia development for decolorization of textile dyes. Biol. Pakistan. 58(1\&2). 53-60.

[13] Governor of East Java Regulation No. 72. 2013. Baku mutu air limbah bagi industri dan/atau kegitan usaha lainnya. East Java Government.

[14] Kumar, B.L., D.V.R. Sai Gopal. 2015. Effective role of indigenous microorganism for sustainble environment. 3 Biotech. 5(6). 867-876.

[15] Varjani, S.J., V.N. Upasani. 2013. Comparative studies on bacterial consortia for hydrocar-bon degradation. Int. J. Innov. Res. Sci. Eng. Technol. 2(10). 5377e5383.

[16] Hachaichi, Z.Z., A. Tazerouti., H. Hacene. 2014. Growth kinetics study of a bacterial consortium producing biosurfactants, constructed with six strains isolated from an oily sludge. Adv. Biosci. Biotech. 5.418-425.

[17] Jaroslawiecka, A., Z. Piotrowska-Seget. 2014. Lead resistance in microorganisms. Microbiol. 160. 12-25.

[18] Sarkar, P., M. Meghvanshi, R. Singh. 2011. Microbial consortia: new approach in effective degradation of organis kitchen wastes. Int. J. Environ. Sci. Dev. 2(3). 170174.

[19] Colak, F., N. Atar, D. Yazicioglou, A. Olgun. 2011. Biosorption of lead from aqueous solutions by Bacillus strains possessing heavy metal resistance. Chem. Eng. J. 173. 422-428.

[20] Vieira, H.S.F. Regine, B. Volesky. 2000. Biosorption: a solution to pollution. Int. Microbiol. 3. 17-24.

[21] Sethuraman, P., M.D. Kumar. 2011. Bacillus subtilis on $\mathrm{Pb}^{2+}$ ions removal from aqueous solution by biosorption. Res. J. Pharm. Biol. Chem. Sci. 2(4). 247.

[22] Mahmood, A., F. Sharif, U. Hyyat. 2013. Biore-mediation of textile effluent by indigenous bacterial consortia and its effects on Zea mays L. CV C1415. J. Anim. Plant Sci. 23(4). 1193-1199. 